\title{
Isolation and Identification of Cellulolytic and Lignolytic Bacteria from the Gut Oryctes rhinoceros $L$. Larvae Decomposition of Oil Palm Empty Fruit Bunches
}

\author{
Isna Rahma Dini, Wawan, Hapsoh, and Sriwahyuni \\ Agrotechnology Department, Agriculture Faculty, Universitas Riau, Indonesia
}

\begin{abstract}
One of the organisms that helps in decomposition of oil palm empty fruit bunches is Oryctes rhinoceros L. larvae. This is because of in the gut of the larvae there are many cellulolytic bacteria and lignoliytic. The process of accelerating the decomposition of oil palm empty fruit bunches into compost can be done by optimizing the work of the bacteria. The aim of this research is to obtain cellulolytic and lignolytic bacteria from larvae $O$. rhinoceros $\mathrm{L}$.. The research succeeded to isolate 24 isolates of cellulolytic bacteria and lignolytic bacterial isolates from the gut of O. rhinoceros larvae. Based on qualitative test, 9 isolate bacteria produced cellulolytic index above 2 . The highest cellulolytic index was generated by ORL19 isolate, while the lignolytic index obtained ORL6 isolate. Based on macroscopic and microscopic identification of bacteria, biochemical and physiological tests, it was found ORL 6 belongs to the genus Bacillus sp. while the ORL 19 belongs to the genus Citrobacter sp..
\end{abstract}

Keywords: cellulolytic index, lignolytic index, oil palm empty fruit bunches, O. rhinoceros larvae.

Received 25 July 2018 | Revised 06 August 2018 | Accepted 20 Augusts 2018

\section{Introduction}

Oil palm empty bunches is one of the waste generated from the processing of oil palm. Every processing of a ton of fresh fruit bunches (FFB) produces $23-25 \%$ oil palm empty fruit bunches, $6.5 \%$ shell, $13-15 \%$ fiber $5.5-6 \%$ seeds and $16-20 \%$ crude palm oil (CPO) [1]. Data from the Directorate General of Plantation 2014 showed that CPO production in 2013 in Riau Province reaches 6.6 million tons with oil palm empty fruit bunches waste reaching 9.4 million tons. It is expected to increase by $7 \%$ every year in line with increased palm oil production [2].

Utilization of waste that has not maximized causing much accumulation of oil palm empty fruit bunches in factories and oil palm plantations. Composting it naturally takes about 3 months, this is because the composition of it is difficult to decompose, which consists of $33.25 \%$ cellulose,

*Corresponding author at: Agrotechnology Department, Agriculture Faculty, Universitas Riau, Kampus Bina

Widya KM.12,5 Panam Pekanbaru 28293, Indonesia

E-mail address: isnarahmadini19@gmail.com 
$56.49 \%$ holocellulose, $23.24 \%$ hemicellulose and $25.83 \%$ lignin [3]. So far oil palm empty fruit bunches used as raw material for compost fertilizer, but constrained in the length of the composting process.

Efforts that can be done to accelerate the process of decomposition of organic materials one of them is by the addition of microorganisms. Microorganisms that can accelerate the decomposition process of oil palm empty fruit bunches are suspected to be in the digestion of larvae O. rhinoceros L., this is because it is a food source for the larvae. The results of study, successfully isolated 28 bacterial strains from the larval digestive tract $O$. rhinoceros $\mathrm{L}$. and 3 of them showed the highest cellulolytic activity, Bacillus pumilus, B. cereus and B. Subtilis [4]. The ability of cellulolytic bacteria in degrading oil palm empty fruit bunches is influenced by the enzyme cellulase produced by the bacteria that can break down cellulose into its sugar derivative compound [5]. Sugar formed during the decomposition process can be a source of energy for the growth of these cellulolytic bacteria so as to accelerate the decomposition process of oil palm empty fruit bunches [6].

The constituents of oil palm empty fruit bunches that are difficult to decompose other than cellulose are hemicellulose and lignin. Hemicellulolytic bacteria are also present in the digestive tract of larvae $O$. rhinoceros $\mathrm{L}$. According to the results of the total 11 isolates isolated from the digestive tract of $O$. rhinoceros L [7]. larvae were all capable of hydrolyzing mannan and xylan which were the components of the hemicellulosic composer, where the highest mannanolytic activity by Bacillus aryabhattai and the highest xylanolytic activity by Bacillus pumilus.

Larvae $O$. rhinoceros $\mathrm{L}$. is one of the sources of cellulose and hemicellulose degrading bacteria [7], but research on the bacteria's ability to degrade lignin has never been done. The objective of this research was to obtain bacteria from $O$. rhinoceros L. larvae which have potential as oil palm empty fruit bunches composition.

\section{Materials and Methods}

The organisms used as the isolates source were instar 2 and 3 instars of O. rhinoceros extracted from PTPN V Sei Plantation Sei Galuh. The isolation medium used is Nutrient Agar (NA). Media screening of bacteria using cellulolytic media $0,02 \% \mathrm{MgSO}_{4} .7 \mathrm{H}_{2} \mathrm{O} ; 0,03 \% \mathrm{NH}_{4} \mathrm{NO}_{3}$; $0,05 \% \mathrm{~K}_{2} \mathrm{HPO}_{4} ; 0,1 \% \mathrm{KH}_{2} \mathrm{PO}_{4} ; 0,002 \% \mathrm{FeSO}_{4} .7 \mathrm{H}_{2} \mathrm{O} ; 0,004 \% \mathrm{CaCl}_{2} .2 \mathrm{H}_{2} \mathrm{O} ; 0,2 \%$ yeast extract, $1 \% \mathrm{CMC}$, and $1.5 \%$ for bacto. Lignolytic bacterial screening using $1 \%$ trypton, $1 \% \mathrm{NaCl}$, and $0.5 \%$ yeast extract and $1.5 \%$ agar bacto [8]. 


\subsection{Isolation of Bacteria from Larva O. rhinoceros}

A total of $1 \mathrm{~g}$ of the gastrointestinal tract of larvae was homogenized using a physiological solution $(\mathrm{NaCl} 0.85 \%)$ by a series dilution method. The diluted solution of $10^{-4}-10^{-7}$ was each taken as $100 \mu \mathrm{l}$ using a micro pipette then dripped and leveled over the surface of the NA medium. Isolates were incubated for one to three days at room temperature [9]. Subsequently isolates were grown purified onto a new NA medium to obtain pure isolates.

\subsection{Qualitative Test of Cellulolytic Capability}

A qualitative bacterial test was performed by bottling one ose of pure isolate on a CMC medium and incubated for 5 days at $37^{\circ} \mathrm{C}$. Furthermore, the isolate growing on the media was flooded with $15 \mathrm{ml}$ of congo red $0.1 \%$ for 30-60 minutes. After that was rinsed 2 times with $15 \mathrm{ml}$ of $1 \% \mathrm{NaCl}$ and silenced again for 15 minutes [10]. Celluloyitic index or Cellulolytic Activity Index (IAS) was obtained by using [11] in [10].

\subsection{Qualitative Test of Lignolytic Ability}

The lignolytic ability test was performed by bottling 1 ose isolate which was 48 hours old 1 ose then inoculated on LB medium and methylene blue for 24 hours at $30^{\circ} \mathrm{C}$. The resulting clear zone indicates that the microb is producing an enzyme that can degrade lignin [12]. Observation of ligninase activity was done by measuring the diameter of the colony and the diameter of the clear zone formed using the sliding term. The ligninase activity index is calculated as the ratio between the diameter of the clear zone and the diameter of the colony.

\subsection{Identification of Potential Bacteria}

Identification of potential bacteria cellulolytic and lignolytic conducted several stages that was by looking at the microscopic character through gram staining and physiological and biochemical tests. Gram staining was done by the method of [13]. Purple bacteria are classified into Gram positive bacteria and red bacteria are classified into Gram-negative bacteria [14]. Biochemical tests consist of carbohydrate fermentation test (mannitol, maltose, sucrose, and glucose test), MR test and test VP. Physiological test was oxygen requirement test.

\section{Results and Discussion}

\subsection{Test of Cellulolitic and Lignolytic Potential}

The isolation of bacteria from the digestion of O. rhinoceros L. larvae was obtained by 24 pure isolates with the code of ORL 1, ORL 2, ORL 3 to ORL 24. Of these 24 isolates, 9 were able to grow on cellulolytic and lignolytic test media, ie ORL 1, ORL2, ORL4, ORL6, ORL 7, ORL8, ORL17, ORL 19 and ORL24. The result of potential bacteria isolate test can be seen in Figure 1 . 


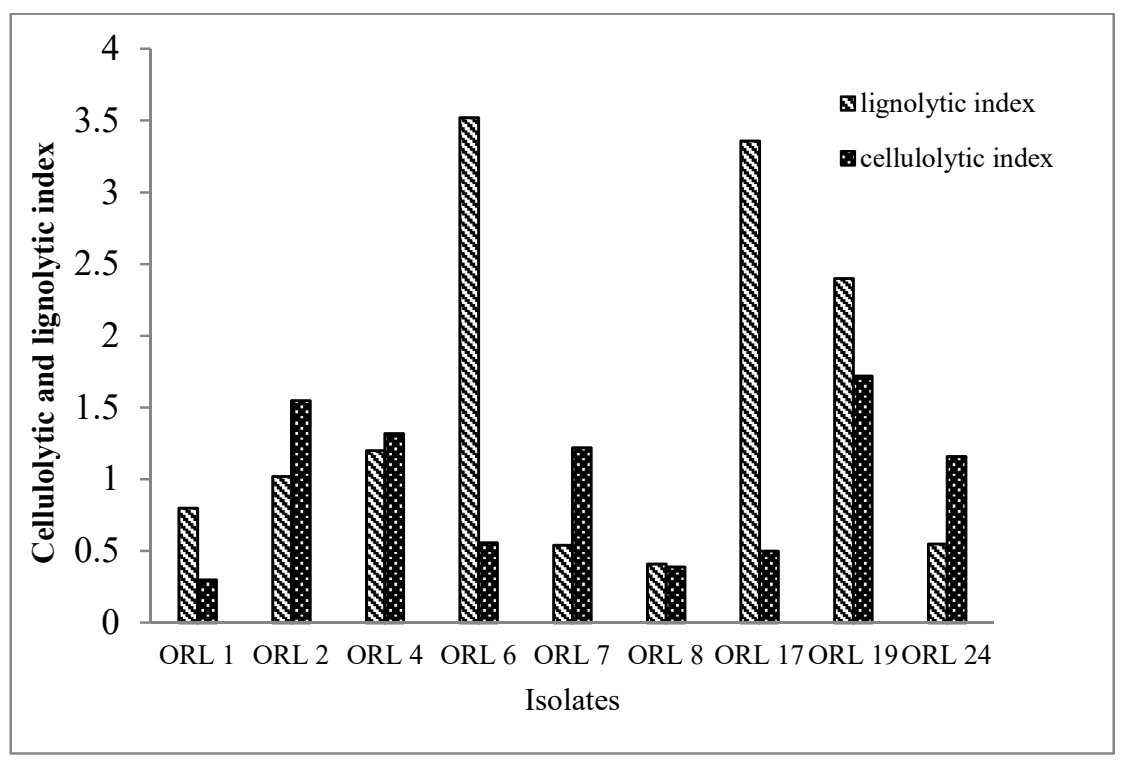

Figure 1. Cellulolytic and Lignolytic Index of Bacterial Isolates

Figure 1 showed that 9 bacterial isolates have the potential to produce various cellulases and lignases in each isolate. The value of cellulolytic and lignolytic activity is strongly influenced by the ability of bacteria to produce its enzymes. The bacteria isolate produced the highest index of cellulolitic activity ie isolate with the code of ORL 19 of 2, whereas the bacteria isolate yielding the highest lignolytic activity index was ORL 6 isolate of 3.52.

The ability of bacteria in degrading cellulose is characterized by the formation of clear zones on CMC media. According to [15], the use of CMC as an activity test medium because CMC is a derivative of water-soluble cellulose that triggers bacteria to excrete cellulase enzymes that break down cellulose into glucose. [16] added that due to the hydrolysis of cellulose into glucose in CMC solid medium, around the colony there appears a brighter region called a cleared zone. This bright zone is the indicator that inoculated bacterial isolates are capable of decomposing cellulose.

Clear zone formation is enhanced by the addition of Congo Red reagents. Congo Red is able to bind ((1-4) - $\beta$-D-glucan causing red colour [17]. The presence of hydrolysis (1-4) - $\beta$-Dglycosidic causes a decrease in the intensity of the resulting colour. Clearly coloured areas around the colonies indicate the presence of cellulose hydrolysis by cellulase enzymes [18]. The clear zone formed due to enzymes secreted by bacterial cells either cellulase, pectinase or lignase does not occur binding by Congo Red [19].

The diameter of the cellulolytic bacteria clear zone is generally larger than the diameter of the bacterial colony. This is because cellulase enzymes are secreted into the environment around bacteria [20]. Cellulolytic activity of bacteria was measured by calculating index value of cellulolitic activity based on [11] method. The cellulolytic activity index is the ratio between the diameter of the clear zone and the diameter of the bacterial colony. 
According to [21], the large or small cellulolytic index produced by bacteria signifies the strong ability of bacteria in degrading cellulose. [22] adds that the greater the clear zone formed the higher the cellulolytic activity.

The magnitude of the ability of 9 bacteria in producing cellulase is also seen in lignolytic, namely the ability of bacteria to decompose lignin. Lignin is a complex compound comprising subimmethoxylated, monomethoxylated and non-methoxyphenyl phenylpropane units [23]. Lignin is found mostly in secondary plant cell walls. The compound fills the gap between cellulose, hemicellulose and pectin, making the cell wall more rigid, hydrophobic and difficult to degrade by microorganisms [24].

Testing of lignolytic ability qualitatively by measuring the clear zone produced on Luria Bertani (LB) medium which is given lignin derivative dye that is methylene blue [8]. The formation of clear zones indicates that the bacterial colonies produce enzymes that degrade the surrounding lignin [12]. [25] reported that methylene blue may also be used for lignolytic performance testing quantitatively by looking at the degree of lignin peroxidase demylation to methylene blue.

The results showed that bacteria isolated from the digestive tract of O. rhinoceros L. larvae had different abilities in degrading lignin. This is evident from the size of the clear zone formed on the test medium and the lignolytic index value index. Isolate with code ORL 6 has the highest lignolytic index value index that is 3.52 , followed by ORL 17 with value 3,36 and ORL 19 with value 2,4 . The index value of the lowest lignolytic activity is ORL 8 with a value of 0.41 . According to [12] clear zone formed indicates the presence of methylene blue degradation by bacterial isolates.

\subsection{Identification of Potential Bacterial Isolates}

Identif ication of bacteria from the digestive larvae of $O$. rhinoceros $\mathrm{L}$. was performed to determine the nine types of potential bacteria in producing cellulase and lignase. Identification is done to include macroscopic and microscopic morphology. Macroscopic colony morphological observations were seen in a single colony of pure cultures. [26] states that observations of bacterial morphology in macroscopic terms include shapes, edges, colours and bacterial elevation. Characteristics of bacterial microscopic morphology were observed by Gram staining. Gram staining is one of the most widely used procedures for classifying various bacteria [27]. According to [28], Gram staining is used to determine the morphology of bacterial cells as well as to distinguish Gram positive and Gram negative bacteria. The results of morphological observations of bacterial colonies both macroscopically and microscopically can be seen in Table 1. 
Table 1. Morphology of Bacterial Colonies Both Macroscopically and Microscopically

\begin{tabular}{|c|c|c|c|c|c|c|}
\hline \multirow{2}{*}{$\begin{array}{l}\text { Isolate } \\
\text { code }\end{array}$} & \multicolumn{4}{|c|}{ Macroscopic morphology of bacteria } & \multicolumn{2}{|c|}{$\begin{array}{l}\text { Microscopic } \\
\text { bacteria }\end{array}$} \\
\hline & Colonies & $\begin{array}{c}\text { Colony } \\
\text { Edge }\end{array}$ & Colour & Elevation & Gram & $\begin{array}{c}\text { Cell } \\
\text { Forms }\end{array}$ \\
\hline ORL 1 & $\begin{array}{l}\text { Spherical with } \\
\text { a tangled } \\
\text { surface }\end{array}$ & Wavy & $\begin{array}{l}\text { Milky } \\
\text { white }\end{array}$ & Arises & + & Bacil \\
\hline ORL 2 & $\begin{array}{l}\text { Irregular } \\
\text { spread }\end{array}$ & Lobal & $\begin{array}{l}\text { Milky } \\
\text { white }\end{array}$ & Convex & - & Bacil \\
\hline ORL 4 & Filiform & Wavy & Clear white & Convex & - & Bacil \\
\hline ORL 6 & Round & Smooth & $\begin{array}{l}\text { Milky } \\
\text { white }\end{array}$ & Convex & + & Bacil \\
\hline ORL 7 & $\begin{array}{l}\text { Irregular } \\
\text { spread }\end{array}$ & Branch & Clear white & Arises & - & Bacil \\
\hline ORL 8 & Rhizoid & Irregular & $\begin{array}{l}\text { Milky } \\
\text { white }\end{array}$ & Convex & - & Bacil \\
\hline ORL 17 & Bulat & Smooth & Clear white & Arises & - & Bacil \\
\hline ORL 19 & $\begin{array}{l}\text { Round with } \\
\text { edges emerge }\end{array}$ & Irregular & Clear white & Flat & - & Bacil \\
\hline ORL 24 & Filiform & Wavy & $\begin{array}{l}\text { Milky } \\
\text { white }\end{array}$ & Arises & - & Bacil \\
\hline
\end{tabular}

Based on observations of colonies of selected bacterial isolates, it is dominated by rounded colonies with different shapes. Based on [13], the edge of the colony seen in the petri dish can be a slippery, irregular, shimmering, jagged and choppy edge. According to [29], the difference in the shape of growth of each bacterial isolate in the cup medium to indicate that all isolates come from different types of bacteria, where the colony form can be used as the basis for bacterial identification. [26] added that based on the morphological characteristics of bacterial colonies and pure cultures can be done the process of identification of the types of microorganisms. Table 1 also shows that there are seven bacterial isolates from the digestive tract of $O$. rhinoceros L. larvae which are Gram negative (ORL 2, ORL 4, ORL 7, ORL 8, ORL 17, ORL 19, ORL 24) and two other isolates are Gram positive (ORL 1 and ORL 6) with the cell form entirely of bacil.

\subsection{Biochemical and Physiological Test of Bacteria}

Biochemical and physiological tests are the tests used to determine the properties of bacteria isolated from the digestive tract of O. rhinoceros L larvae. Each bacterial isolate is tested on a series of media to view its biochemical and physiological activity. Biochemical tests performed include carbohydrate fermentation test (glucose, sucrose, maltose and mannitol), MR (Methyl Red) test, and VP (Voges Proskauer) test, while physiological test is oxygen demand test. The result of biochemical test can be seen in Table 2 . 
Table 2. Biochemical Test Results of Bacteria

\begin{tabular}{|c|c|c|c|c|c|c|}
\hline \multirow{2}{*}{$\begin{array}{c}\text { Isolate } \\
\text { Code }\end{array}$} & \multicolumn{4}{|c|}{ Carbohydrate Fermentation Test } & \multirow{2}{*}{ MR Test } & \multirow{2}{*}{ VP Test } \\
\hline & Glucose & Sucrose & Maltose & Mannitol & & \\
\hline Control & - & - & - & - & - & - \\
\hline ORL 1 & + & + & + & + & - & + \\
\hline ORL 2 & + & + & + & + & + & - \\
\hline ORL 4 & + & + & + & + & - & + \\
\hline ORL 6 & + & + & + & + & - & - \\
\hline ORL 7 & + & + & - & + & + & - \\
\hline ORL 8 & + & + & + & + & - & - \\
\hline ORL 17 & + & + & + & + & - & - \\
\hline ORL 19 & + & + & + & + & - & - \\
\hline ORL 24 & + & + & + & + & + & - \\
\hline
\end{tabular}

Information:

ORL : O. rhinoceros larvae

$+\quad$ : Change colour

- $\quad$ : It does not change colour

The nature of bacterial metabolism in biochemical tests is usually seen from the interaction of metabolites produced against chemical reagents. The nature of bacterial metabolism can also be seen from the ability of bacteria in using certain compounds as a source of carbon and energy sources [30]. The result of biochemical test in Table 3 shows that each isolate has different biochemical activity. According to [30], the biochemical activity of each type of bacteria is different because each bacterium has different enzymatic activity, therefore the biochemical test stage is very influential in distinguishing the genus found.

The results of bacterial carbohydrate fermentation test showed positive results, except isolate ORL 7 which showed negative result on maltose test. Similarly, MR test showed 2 isolates which showed positive result that ORL 2 and ORL 24 and 7 other isolates showed negative result while in VP test there were 2 isolates showing positive result that ORL 1 and ORL 4 and 7 other isolates showed negative result.

\subsection{Oxygen Needs Test}

Oxygen demand test is performed to see the ability of bacteria in utilizing oxygen using Oxidative-Facultative (OF) media. According to [26], bacteria can be sorted according to the need for oxygen, including obligate aerobes, obligate anaerobes, facultative anaerobes and microaerophils. The oxygen demand test results can be seen in Table 3 . 
Table 3. Results of bacterial oxygen demand test from larvae O. rhinoceros L.

\begin{tabular}{cccc}
\hline \multirow{2}{*}{ Isolate Code } & \multicolumn{2}{c}{ Colour Change } & \multirow{2}{*}{ Information } \\
\cline { 2 - 4 } & Anaerob Test & Aerob Test & \\
\hline Kontrol & - & - & - \\
\hline ORL 1 & + & + & Facultative Anaerob \\
\hline ORL 2 & + & - & Anaerob \\
\hline ORL 4 & + & - & Anaerob \\
\hline ORL 6 & + & + & Facultative Anaerob \\
\hline ORL 7 & + & - & Anaerob \\
\hline ORL 8 & + & - & Anaerob \\
\hline ORL 17 & + & + & Facultative Anaerob \\
\hline ORL 19 & + & + & Facultative Anaerob \\
\hline ORL 24 & + & - & Anaerob \\
\hline
\end{tabular}

Information:

ORL : O. rhinoceros larvae

$+\quad$ : Changed colour

- $\quad$ : It does not change colour

Based on the morphological, biochemical, and physiological identification of nine bacterial isolates, ORL 1, ORL 2, ORL 4, ORL 6, ORL 7, ORL 8, ORL 17, ORL 19 and ORL 24 refer to the book Bergey's Manual of Determinative Bacteriology 7th edition, the ORL 1 and ORL 6 belong to the genus Bacillus sp., ORL 2 belong to the genus Proteus sp., ORL 4 belong to the genus Ochrobactrum sp., ORL 7 belong to the genus Erwinia sp., ORL 8 included in the genus Aeromonas sp ., ORL 17 and ORL 19 belong to the genus Citrobacter sp. and ORL 24 belong to the genus Pseudomonas sp..

The results of [4] study found 28 bacterial strains isolated from the digestive tract of the $O$. rhinoceros L. larvae, three of which yielded the highest cellulolytic activity then based on morphological and biochemical characteristics indicating these bacteria were Bacillus pumilus, Bacillus cereus and Bacillus subtilis. The results of research [7] added that 11 bacteria isolated from the digestive tract of larval O. rhinoceros L. were identified, 10 of which belong to the genus Bacilus sp. and one isolate belongs to the genus Citrobacter sp .

Cellulolytic and hemicelulolytic bacteria can be found almost in all insect digestive tracts, such as in the gut of Oryctes rhinoceros larvae [7], in Bombix mori larvae [31], Holotrichia parallela larvae [32], on insects like Reticulitermes flavipes [33], Anoplophora glabripennis [34], and Attacus atlas L. [35], capable of degrading plant biomass with the aid of microorganisms found in the digestive tract.

Herbivorous animals are able to utilize cellulose as a source of energy. This ability is supported by the presence of microorganisms in the digestive tract that mempu produce cellulase enzyme. Based on the results of the study of [7], from a total of 11 isolates isolated from the digestive tract of $O$. rhinoceros L. larvae, $63.6 \%$ were cellulolytic bacteria, $72.7 \%$ xylanolytic and $100 \%$ mannanolytic. [7] added that the O. rhinoceros L. larvae are the best source for studying 
cellulolytic, xylanolitic and mannanolytic microorganisms and their enzymes that are particularly useful for degrading lignocellulose.

\section{Conclusion}

The results of bacterial screening from the digestive larvae of O. rhinoceros L. were obtained as many as 24 bacterial isolates, nine of which were potential as oil palm empty fruit bunches compositions which were demonstrated by the cellulolytic and bacterial lignolytic potential test with ORL 1, ORL 2, ORL4, ORL 7, ORL 8, ORL 17, ORL 19 and ORL 24. Isolates yielding the highest cellulolitic index on ORL 6, while lignolytic in ORL19.

Based on the results of macroscopic and microscopic identification of bacteria and bacterial biochemical and physiological tests, it was suspected that the isolates of ORL 1 and ORL 6 belong to the genus Bacillus sp., ORL 2 belonging to the genus Proteus sp., ORL 4 belongs to the genus Ochrobactrum sp., ORL 7 belongs to the genus Erwinia sp., ORL 8 belongs to the genus Aeromonas sp., ORL 17 and ORL 19 belongs to the genus Citrobacter sp. and ORL 24 are included in the genus Pseudomonas sp. Further identification is required on these 9 isolates to molecular identification potential bacterial species as cellulolytic and lignolytic bacteria.

\section{Acknowledgments}

Thanks to the Universitas Riau through the fund of List of Budget Execution (DIPA) University of Riau 2018, No: 773/UN.19.5.1.3/PP/2018 which has funded this research activity.

\section{REFERENCES}

[1] Y. Fauzi, Y. E. Widiyastuti, I. Satyawibawa, and R. H. Paeru, Kelapa Sawit: Budidaya, Pemanfaatan Hasil dan Limbah, Analisis Usaha dan Pemasaran. Jakarta: Penebar Swadaya, 2005.

[2] A. Sunaryo, M. Anggito, and M. Sumringahgesit, "Hydrolysis of a lignocellulosic materials oil palm empty fruit bunch for ethanol production," Biomaterial Technology, vol. 803, pp. 1-11. 2013.

[3] D. P. Dewanti, "Potensi Selulosa dari Limbah Tandan Kosong Kelapa Sawit untuk Bahan Baku Bioplastik Ramah Lingkungan,” Jurnal Teknologi Lingkungan, vol. 19, no. 1, pp. 8188, 2018.

[4] W. Hidayat, "Isolasi dan skrining bakteri cellulolytic dari saluran pencernaan larva $O$. rhinoceros (Coleoptera: Scarabaeidae)," Skripsi, Fakultas Matematika dan Ilmu Pengetahuan Alam, Universitas Negeri Sebelas Maret, Surakarta, 2013.

[5] T. C. dos Santos, D. P. P. Gomes, R. C. F. Bonomo, and M. Franco, "Optimisation of solid state fermentation of potato peel for the production of cellulolytic enzyme," Food Chemistry, vol. 133, pp. 1299-1304, 2012.

[6] A. S. Baharuddin et al., "Isolation and characterization of thermophilic cellulase-producing bacteria from empty bunches-palm oil mill effluent compost," Journal of Applied Science, vol. 7, no. 1, pp. 56-62, 2010. 
[7] S. L. A. Sari et al., "Cellulolytic and hemicellulolytic bacteria from the gut of $O$. rhinoceros larvae," Jurnal Biodiversitas, vol. 17, no. 1, pp. 78-83, 2016.

[8] L. Bandounas, N. J. P. Wierckx., J. H. de Winde, and H. J. Ruijssenaars, "Isolation and characterization of novel bacterial strains exhibiting ligninolytic potential," Journal of BMC Biotechnology, vol. 11, no. 94, 2011.

[9] T. I. Sunatmo, Eksperimen Mikrobiologi dalam Laboratorium. Jakarta: Ardy Agency. 2009.

[10] E. Chasanah, I. R. Dini, and N. R. Mubarik, "Karakterisasi enzim selulase PMP 0126Y dari limbah pengolahan agar," Jurnal Pengolahan dan Bioteknologi Perikanan, vol. 8, no. 2, pp. 103-114, 2013

[11] A. J. Kader and O. Omar, "Isolation of cellulolytic fungi from Sayap Kinabalu Park, Sabah. Serawak," Journal Biodiversity Bio-Conserv (ARBEC), pp. 1-6, 1998.

[12] H. T. Prakoso, H. Widiastuti., Suharyanto, and Siswanto, "Eksplorasi dan karakterisasi bakteri aerob lignolytic serta aplikasinya untuk pengomposan tandan kosong kelapa sawit," Jurnal Menara Perkebunan, vol. 82, no. 1, pp. 15-24, 2014.

[13] J. G. Cappucino and N. Sherman, Microbiology: A Laboratory Manual. Wesley: Addison, 1983.

[14] S. T. Pratiwi, Mikrobiologi Farmasi. Jakarta, Erlangga, 2008.

[15] M. Lamid, T. P. Nugroho, S. Chusniati, and K. Rochiman, "Eksplorasi bakteri selulolitik asal cairan rumen sapi potong sebagai bahan inokulum limbah pertanian," Jurnal Ilmiah Kedokteran Hewan, vol. 4, no. 1, 2011.

[16] M. Alexander, Introduction to Soil Microbiology. Second Edition. New York, John and Sons, 1976.

[17] R. Khurana, V. N. Uversky, L. Nielsen, and A. L. Fink. (2011). Is Congo red an amyloid specific dye?. Journal of Biological Chemistry. [Online]. Available: http://www.jbc.org/content/276/25/22715.full

[18] R. F. Fadilah, "Isolasi and identifikasi bakteri selulolitik pengurai sampah organik dari berbagai tempat," Skripsi, Fakultas Ilmu Pengetahuan Alam dan Matematika, Universitas Pendidikan Indonesia, 2012.

[19] Sutoyo and K. Muzakhar, "Skrining dan identifikasi bakteri endosimbiotik dalam usus rayap penghasil selulase," Jurnal Pengendalian Hayati, vol. 1, no. 2, pp. 104-110, 2008.

[20] V.V. Zverlova, W. Holl, and H. Schwarz, "Enzymes for digestion of cellulose and other polysaccharides in the gut of longhorn beetle larvae, Rhagium inquisitor L. (Col., Ccerambycidae)." International Biodeterioration \& Biodegredation, vol. 5, no. 3, pp. 175179, 2003.

[21] Fikrinda, "Isolasi dan karakterisasi bakteri penghasil selulase ekstermofilik dari ekosistem air hitam," Tesis Program Pascasarjana, IPB, Bogor, 2000.

[22] C. L. Aguiar, "Biodegradation of the cellulose from sugarcane bagasse by fungal cellulase," Journal of Science Technology Aliment, vol. 3, pp. 117-121, 2001.

[23] A. T. Martinez et al., "Biodegradation of lignocellulosics: microbial, chemical and enzymatic aspects of the fungal attack of lignin". Journal of International Microbiol, vol. 8, no. 3, pp. 195-204, 2005.

[24] T. D. Bugg, M. Ahmad., E. M. Hardiman, and R. Singh, "The emerging role for bacterial in lignin degradation and bio-product formation," Journal of Current Opinion in Biotechnology, vol. 22, pp. 1-7, 2010.

[25] A. D. Bholay et al., "Bacterial lignin peroxidase: A tool for biobleaching and biodegradation of industrial effluents," Journal Environment Res Technol, vol. 2, no.1, pp. 58-64, 2012. 
[26] R. S. Hadioetomo, Mikrobiologi Dasar dalam Praktek Teknik dan Prosedur Dasar Laboratorium. Jakarta: Gramedia, 1993.

[27] A. Anuar, A. Dahliaty, and C. Jose, "Isolasi bakteri selulolitik dari perairan dumai," Jurnal Online Mahasiswa, vol. 1, no. 2, 2014.

[28] Rostinawati, "Skrining dan identifikasi bakteri penghasil enzim kitinase dari air laut di perairan pantai Pondok Bali," Penelitian Mandiri, Fakultas Farmasi, Universitas Padjadjaran, Jatinangor, 2008.

[29] W. A. Volk, Mikrobiologi Dasar. Terjemahan Soenartono Adisoemarto. Jakarta, Erlangga, 1998.

[30] L. Waluyo, Mikrobiologi Umum. Malang: UMM Press, 2004.

[31] A. A. P. Anand et al., "Isolation and characterization of bacteria from the gut of Bombyx mori that degrade cellulose, xylan, pectin and strach and their impact on digestion," Journal Insect Science, vol. 10, pp. 1-20, 2010.

[32] S. Huang, P. Sheng, and H. Zhang, "Isolation and identification of cellulolytic bacteria from the gut of Holotrichia parallela larvae (Coleoptera: Scarabaeidae)," International Journal Molecular Science, vol. 13, pp. 2563-2577, 2012.

[33] J. Zhou et al., "Identification and purification of the main components of cellulases from a mutant strain of Trichoderma viride T100-14," Journal Bioresour Technology, vol. 99, pp. 6826-6833, 2008.

[36] S. M. Geib, M. Tien, and K. Hoover, "Identification of proteins involved in lignocellulose degradation using in gel zymogram analysis combined with Mass Spectroscopy-based peptide analysis of gut proteins from larva Asian plonghorned beetles, Anoplophora glabripennis," Journal Insect Science, vol. 17, pp. 253-264, 2010.

[37] S. L. A. Sari, A. Pangastuti, and S. Winarseh. Penampisan bakteri cellulolytic dari saluran pencernaan Attacus atlas L," in Proceeding of prosiding Seminar Nasional Mikrobiologi: Keanekaragaman dan Pemanfaatan Sumberdaya Mikroba Tropika Indonesia, 2014, pp. 3640. 